\title{
SETTING THE AFTER SALE PROCESS AND QUALITY CONTROL AT CAR DEALERSHIPS TO THE PURPOSE OF INCREASING CLIENTS SATISFACTION
}

\author{
Igor Stevanović* \\ Porsche Beograd Ada , Belgrade, Serbia \\ Darko Stanojević \\ University of Belgrade, Faculty of Mechanical Engineering, Belgrade, Serbia \\ Aleksandar Nedić \\ Insurance Company Dunav, Belgrade, Serbia
}

In a service department it is necessary to provide quality service in order to achieve clients' satisfaction and loyalty, as well as increasing profit. This also applies to service garages. The aim of this paper is to create the service of vehicle maintenance based on clients' demands. A lot of activities which require the control system are recognized during setting the service process. Quality control represents the main factor for successful process applying.

Keywords: Quality control, Car repair, Service process, Clients' demands, Indicators

\section{INTRODUCTION}

The automobile is an object of pleasure, need, necessity, and worship. In Belgrade, there were 1.565 .550 passenger cars in 2010, 1.677 .510 in 2011 and 1.726 .464 in 2012 [08]. Data on selling new cars in Serbia show that there is a big fall in the sales department. That's why the main challenges for profit growth of automobile companies are After Sales activities, i.e. vehicle maintenance. Planning cost of maintenance has become an important home budget item, thus customers expect quality service.

The profit of a company is highly influenced by consumer loyalty. Loyalty is influenced by consumer satisfaction and satisfaction by the quality of provided service [09]. This brings us to the conclusion that client satisfaction is very important for After Sales companies in order to stay competitive on the market. Client satisfaction represents the difference between perceived and expected service [03]. The starting point in this paper is experience, meaning there are 5 core indicators that are important to the owners of passenger cars bringing their cars to service garages. An inquiry about their satisfaction about five indicators is presented in the first part of the paper. Results show that additional activities and controls are necessary beside those currently present in services in Serbia. The service process has been set for auto garages in Serbia for the purpose of consumer satisfaction. Special emphasis has been set on security and following the process by Quality control.

\section{CLIENTS SATISFACTION IN THE SERVICE OF VEHICLE MAINTENANCE}

The term of client's satisfaction in service:

Satisfaction $=$ perceived service - expected service

"Client satisfaction is consumer response to assessment of observed difference between previous expectations (or exact standard performance) and real performances, how he saw it after consuming" [03].

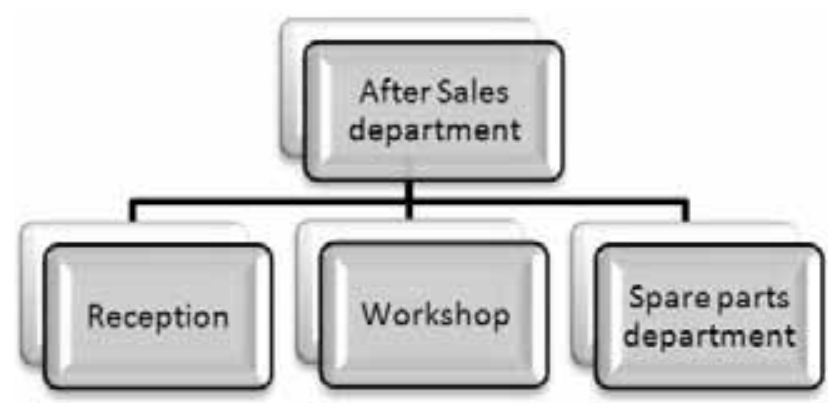

Figure 1: After Sales department

Veljkovic in his own book simplifies this definition: "The satisfaction of the consumers is their emotional response (feeling of satisfaction) which occurs by comparing the expectations formed before purchasing and the perceived performance of the product/service" [04]. In order for the feeling of satisfaction to appear, it is 
necessary at least to fulfill the consumers' expectations. "Consumer expectations are beliefs about the service and its delivery which serve as a standard or reference point, according to which the performance of received service is assessed, i.e. its perception. Therefore, knowledge of consumer expectations is the key point in the creation and delivery of services, i.e. in the entire service business [05]. Factors that affect the clients expectations are internal factors (individual needs, previous experience and service philosophy), external factors (competitive options, social context, „word of mouth“), situational factors (reasons of purchasing, the consumers' mood, time limit, unexpected events) and factors produced by organization (promotion, distribution, service personnel, consumers, the company's image, pre-service waiting) [07]. Perception of service is a way in which the consumer experiencesthe service. The way in which a client sees service depends on the technical quality dimension, the functional dimension and the corporate image [01]. The technical dimension shows what the client gets, and functional in what way.

\section{THE TERM OF VEHICLE MAINTENANCE SERVICE}

The department which is engaged in maintenance / repairing of motor vehicles is called The after Sales department. As shown on figure no.1, it consists of 3 sectors: reception, workshop and spare parts department. Clients who go to service garages have to be received. The reception is in charge of receiving the clients, as well as vehicle delivery after the repair is done. The workshop performs repair work by consumer demand, whereas the parts department delivers parts and necessary tools for the repair work.

\section{SERVICE QUALITY}

Many authors have defined service quality. The most acknowledged is the GAP model of service quality and the SERVQUAL model concept of quality dimensions. SERVQUAL represents a multidimensional scale in order to compare the consumer's perception with expectations in terms of service quality. The obtained result needs to be compared with consumers' answers in terms of expectations. According to this model, there are 10 quality dimensions which ad up to 5 generally accepted core dimensions [02]:

- Reliability (ability to deliver promised service in an appropriate way);
- Responsibility (accuracy and willingness to help and deliver fast service);

- Assurance (knowledge and politeness of the employees and ability to acquire trust in them);

- Empathy (providing personal service observing consumer as an individual);

- Tangible elements (presence of physical elements - materialization of service).

\section{EMPIRICAL ANALYSIS OF CLIENT DEMANDS WITHIN THE SERVICE OF VEHICLE MAINTENANCE}

\section{Description of the study example}

Research was conducted in Belgrade, from 01.02.2013. to 10.03 .2013 . The fact that there were 431.350 passenger cars registered in Belgrade, i.e. $1 / 4$ of total number of vehicles in Serbia, confirms that this is the city with the largest number of passenger cars on the road. Respondents were surveyed by interviews "face to face" and questionnaires. There were 3 surveyors. From a total of 301 questionnaires, 200 correspond to the research target group, who are having their own vehicles, who bring it to the garage personally and who are employed. In this research, authorized garages are separated from those who aren't. According to experience, 3 categories were made about consumers' expectations / demands.

I category: quality of repair work, service done within the agreed time schedule, price, friendliness and professionalism, the time waiting for an appointment.

II category: availability of spare parts, advice given for further maintenance, information given about additional work.

III category: adequate documentation about accomplished work, replace vehicle, to invoices explained, café, Wi-Fi, phone availability.

In this paper only the first category has been taken into consideration.

\section{Questionnaire}

1. Do you own a passenger car and do you drive it to a service garage? YES/NO

2. Are you employed? YES/NO

3. Where do you repair your car? AT AN

AUTHORIZED DEALER / AT AN

UNAUTHORIZED DEALER 
4. What is the most important for you when we talk about repairing your car? (align by relevance):

- not to have to come back to the workshop because of the same malfunction,

- to follow agreed time for service done,

- friendly, professional and efficient personnel,

- not having to wait long for a free appointment,

- fair prices, according to agreed price and to be informed in advance if there are additional repairs.

5.Are you satisfied with the repair service at your garage in the following aspects (Table 1):

Table 1: Questionnaire

\begin{tabular}{|l|c|}
\hline \multicolumn{1}{|c|}{ Item } & Answer \\
\hline $\begin{array}{l}\text { Returning to the workshop } \\
\text { because of the same malfunction }\end{array}$ & YES/NO \\
\hline \hline $\begin{array}{l}\text { Following agreed time } \\
\text { for service done }\end{array}$ & YES/NO \\
\hline $\begin{array}{l}\text { Friendly, professional and efficient } \\
\text { personnel }\end{array}$ & YES/NO \\
\hline \hline Waiting for a free appointment & YES/NO \\
\hline $\begin{array}{l}\text { Price, according to agreed price } \\
\text { and information in advance in case } \\
\text { of additional repairs }\end{array}$ & YES/NO \\
\hline
\end{tabular}

\section{RESULTS AND DISCUSSION}

The research results showed that passenger car owners who maintain their cars at authorized garages are satisfied with the aspect of friendliness and waiting for an appointment. Service staff passes through training which must be accomplished according to the demands of the producer, where they also learn about communication with clients. Clients are not satisfied about having to come back to service garages because of the same problem and work not done according to agreed time or price.

\section{Where do you repair your car?}

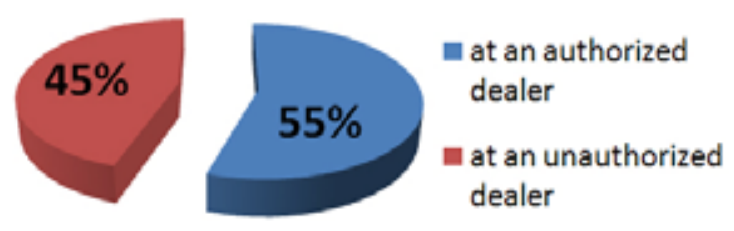

Figure 2: Results for the question "Where do you repair your car"

Authorized services are generally organized so everybody in the service chain has their own responsibilities. Therefore, communication and information transfer must be at the highest level, which could sometimes be a problem in practice. The result is a delay in the completion of the work, as well as errors in the elimination of vehicle malfunction, for which the vehicle owners have to go back to service (Figure 4).

\title{
What is the most important for you when we talk about repairing your car?
}

\author{
Waiting for a free appointment \\ Friendly, professional and efficient \\ personnel \\ Following agreed time for service done \\ Price, agreed price and information in \\ advance in case of additional repairs \\ Returnig to the workshop beacuse of \\ the same malfunction
}

3
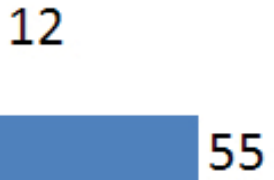

Figure 3: Results for the question about 5 indicators 
On the other hand, vehicle owners that bring cars to unauthorized services were satisfied with the aspect of waiting for an appointment, and prices, but with other indicators they were not satisfied. This is understandable because the unauthorized mechanics rarely refuse a job. If it is necessary, they will stay the whole day at the workshop, unlike authorized dealers who have strict working hours.
Prices are lower than in authorized services, but the question is what the quality of service received for that amount of money is like. As far as coming back to the workshop, the results are similar as with authorized services. This is because of unprofessional mechanics, as well as the lack of expensive tools and diagnostic repair equipment (Figure 5).
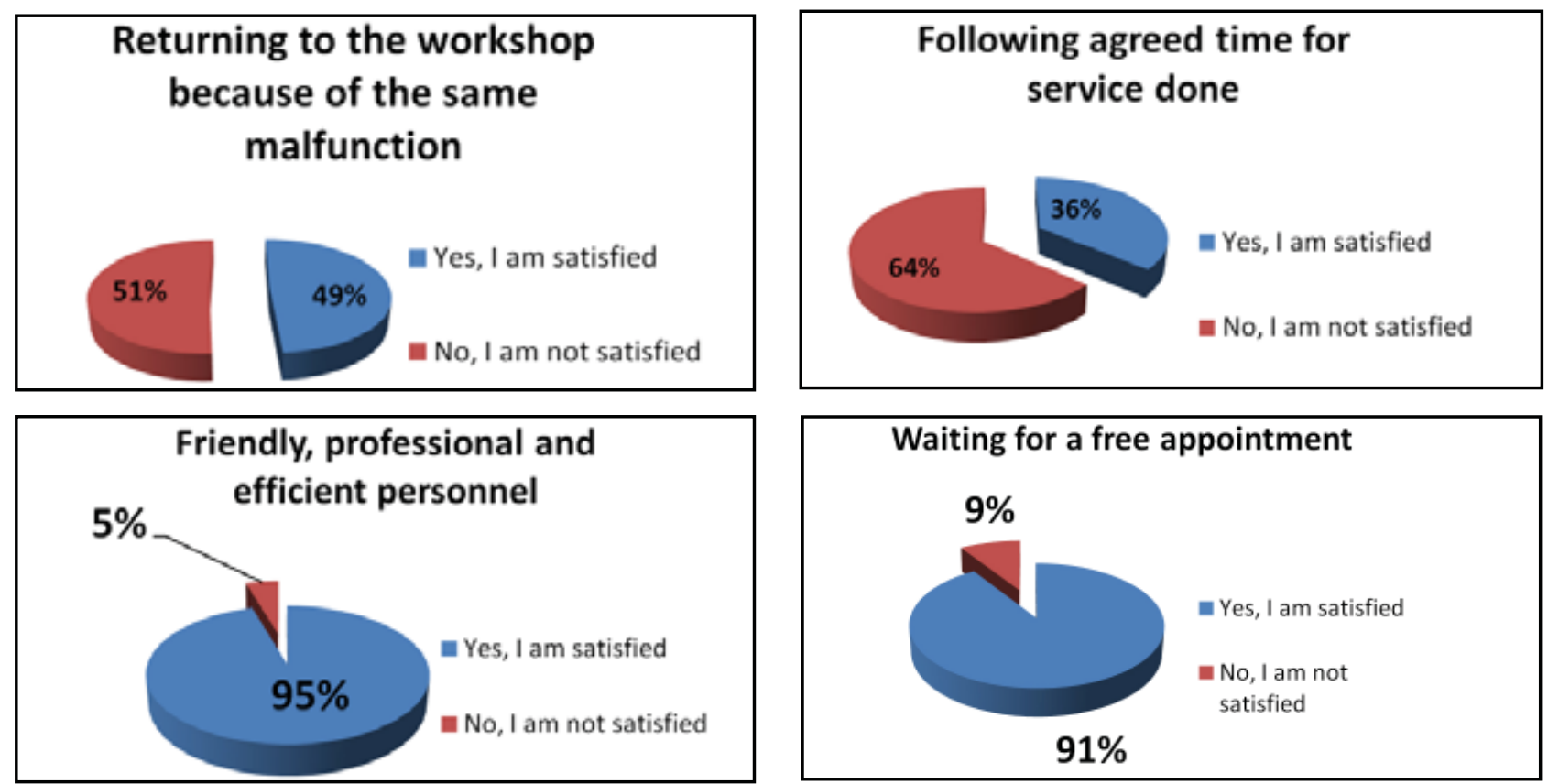

Waiting for a free appointment

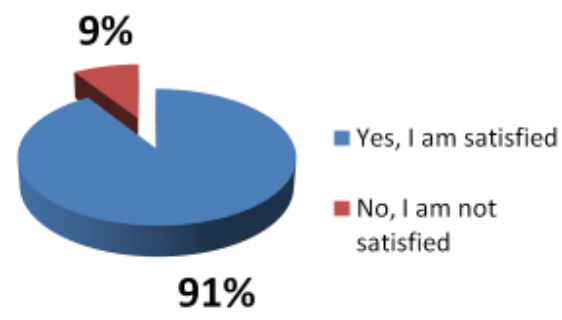

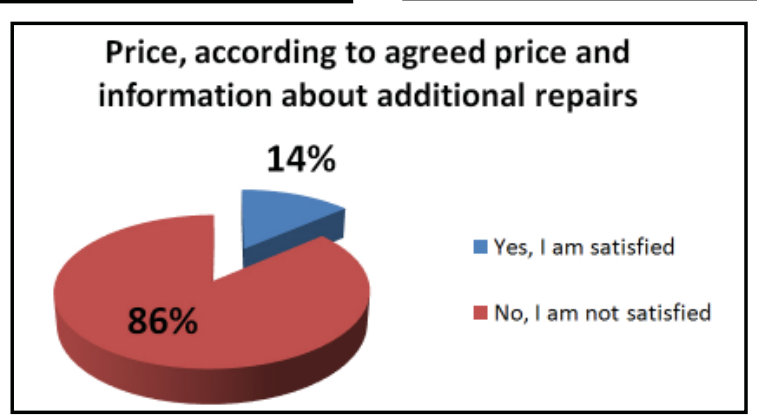

Figure 4: Results about 5 indicators (authorized dealers)

Also, friendliness is not their strong feature, and promised time for finishing the work is not often respected because someone more important always comes in with "just something to look at". So, generally the biggest problem to owners of passenger cars in Serbia, whether it is an authorized or unauthorized dealer, is bad repair quality and the price in terms of what is gained by this amount, followed by promised completion time of the repair. Obviously, the time is one of the most valuable resources, which nowadays is never enough. Price is questionable because what is gained by the amount has to be checked. These aspects are also the top three indicators in order of importance. Accordingly, a quality control model will be introduced in auto service that should enhance the quality of service provided.

\section{SETTING THE SERVICE PROCESS}

According to derived results, it is possible to align following indicators by relevance:

- Returning to the workshop because of the same malfunction;

- Price, respecting agreed price and informing in advance in case of additional repairs;

- Respecting agreed time for service done;

- Friendly, professional and efficient personnel;

- Waiting for an appointment. 

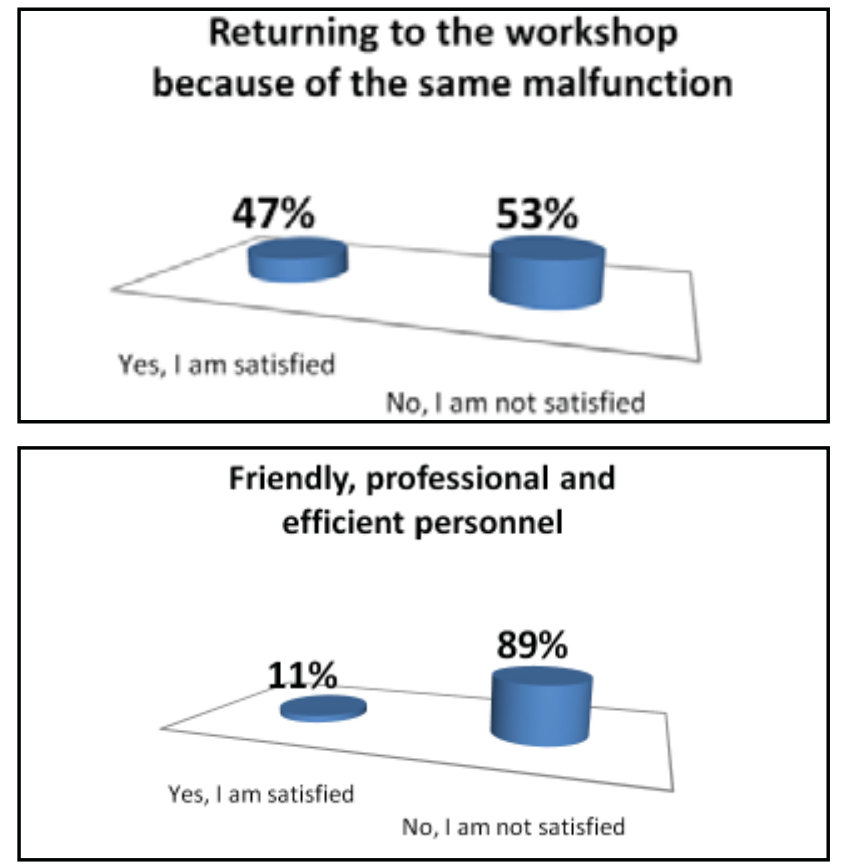

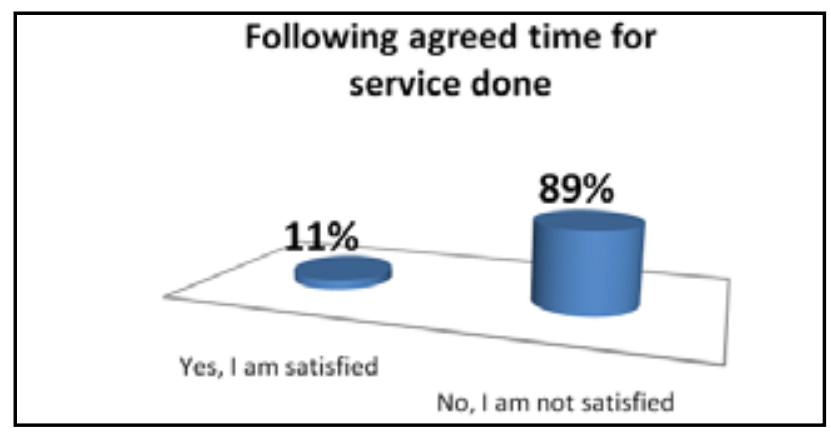

Waiting for a free appointment

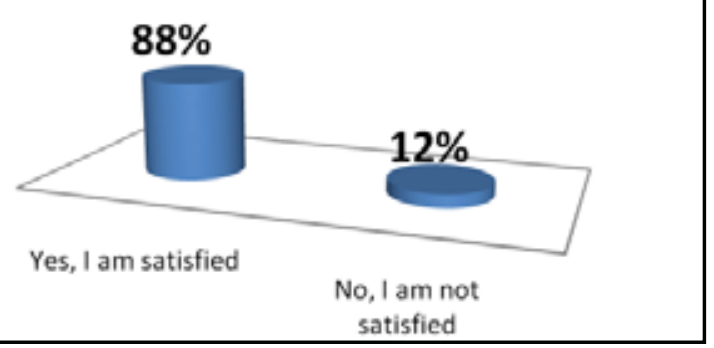

Price, according to agreed price and information about additional repairs

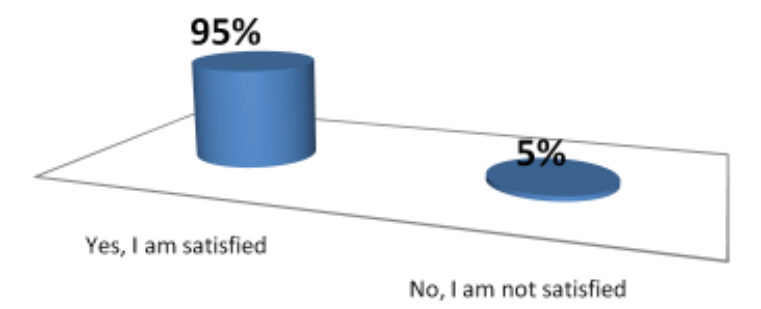

Figure 5: Results about 5 indicators (unauthorized dealers)

It can be said that these are goals for every car service garage, classified by priority.

According to this, it is necessary to set the organizational structure of After Sales departments, as well as the process which will be conducted inside of it.

\section{Setting the service process}

The service process has to have a logical flow. In Figure 6 is shown how this process needs to look like in the widest sense.

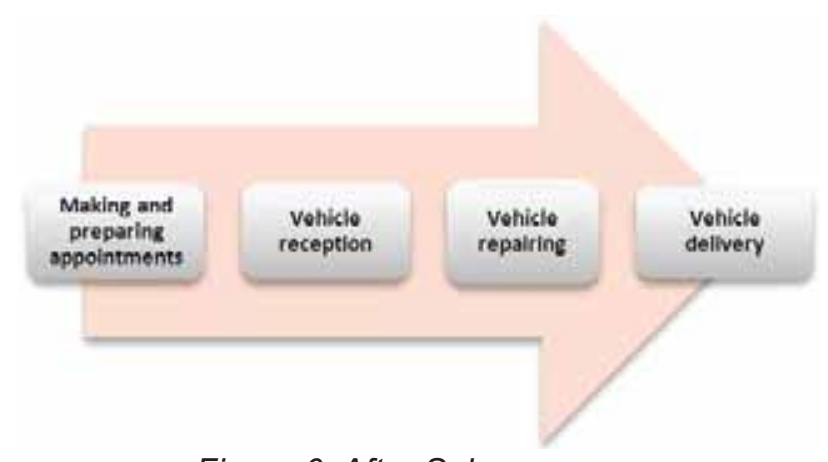

Figure 6: After Sales process
In Table 2 are shown activities which would respond to consumer demands with After Sales departments.

After setting the activities in accordance with consumer demands, it is necessary to determine the role of Quality control in the process. On the right side of the table, activities which are controlled by Quality control are marked.

Every defection of task, Quality control needs to identify and give the subject back to reprocessing. In order to carry out these particular activities adequately, it is necessary to set an organizational structure which is led by the After Sales Manager (Figure 7). Receptionist and service advisor are parts of the Reception department. Workshop manager, mechanic and technical support belong to the workshop. Manager of spare parts department and storekeeper belong to the parts department. The number of positions depends on how big the job is or on how big the object is. The level of top management of the organization is strategic 
level, and at that level the strategic plans are made as well as the determination of the organization, according to the orientation of the business policy [04]. Strategic planning and quality policy in the organization provide establishment of quality goals [06].

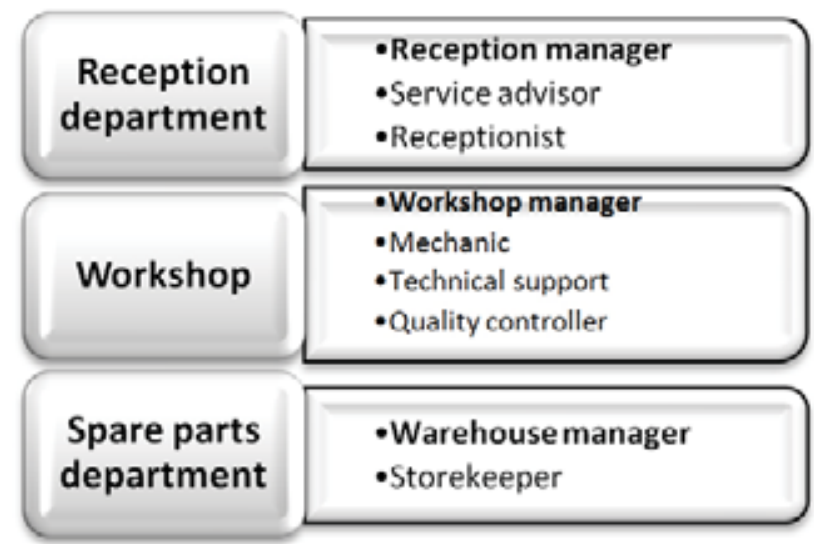

Figure 7: Organizational structure

\section{THE EXAMPLE OF PREVENTIVE MAINTENANCE OF PASSANGER CARS WITH FOCUS ON QUALITY}

There are a lot of activities while delivering car maintenance service. Deviation from them can cause decreasing service quality, thereby the consumer dissatisfaction. Since this is not a goal, it is necessary to set certain quality and check systems. Quality control has the core role in supervising the whole process of car repair service delivery and is an efficient solution which is going to bring benefits both for clients and company (Figure 8).

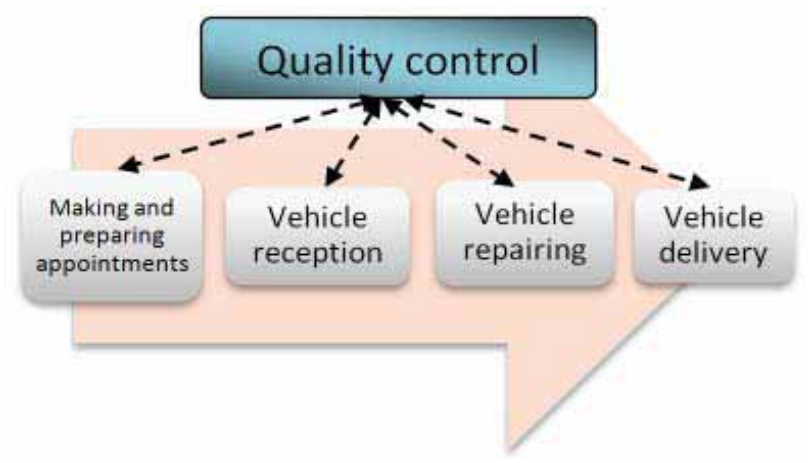

Figure 8: Quality control in the After Sales process

Review of activities which are needed to be controlled by Quality control is shown in Table no.2. Regular maintenance means interval services after a particular mileage or after some particular period of time, whichever expires first. These conditions differ from brand to brand, but usually starting from $10000 \mathrm{~km}$ to $15000 \mathrm{~km}$ or 1 year. These are periods after which it is necessary for the authorized dealers to check systems on vehicles and replace certain parts and fluids. In order to respond to consumer demands according to research in this paper which refers to conducting a quality car repair, it is necessary to provide Quality control. The role and importance of Quality control in the process of delivering car repair service is large, from making appointments, via repairing, to car delivery to the owners. Beside active control of the repair process, it is necessary to have a "check list" for checking the service. Practical example of car repair delivery service and suggestions of control are presented below.

\section{Making appointments and preparing}

The client wants to do regular service on his car. $\mathrm{He}$ makes an appointment regularly with the person in charge of that (receptionist). The quality controller and the manager of the workshop control if the receptionist filled capacity of the workshop and calculated the time for doing the repair.

This is a very important moment because one mistake in the term of planning may disrupt the whole organization and be a cause of not meeting its promises to clients. It has been explained to the client what regular service includes and what the cost is. The receptionist enters all necessary data about the history of maintenance for this vehicle into the software, as well as spare parts availability.

\section{Reception of the vehicle}

The client brings his car to the garage and communicates with the reception department and the service advisor which has been assigned to him in the appointment. The statement about the ordered work has to be confirmed, or changed if it is necessary. The visual control of the vehicle needs to be done in order to check the present condition, such as damages, fuel, first aid, returning of old parts, etc. Ordered work, price and finishing time is stated precisely with the owner. All data are typed electronically in the work order, which is printed afterwards. Thus, the final result of receiving the vehicle is making a service account. The work shop does the work according to the service account. That's why it is important to take the client's statement in a correct and precise way. The quality control, before assigning the case to a workshop, controls the filling out of the service account and all other documentation supplied with it. 
Table 2: Activities of the After Sales process

\begin{tabular}{|c|c|}
\hline ACTIVITY & $\begin{array}{l}\text { QUALITY } \\
\text { CONTROL }\end{array}$ \\
\hline \multicolumn{2}{|l|}{ MAKING AND PREPARING APPOINTMENTS } \\
\hline \multicolumn{2}{|l|}{ Checking the history of the vehicle } \\
\hline \multicolumn{2}{|l|}{ Checking "campaigns“ } \\
\hline \multicolumn{2}{|l|}{ Getting client statement about ordered work } \\
\hline \multicolumn{2}{|l|}{ Spare parts availability } \\
\hline \multicolumn{2}{|l|}{ Giving information about price and paying } \\
\hline \multicolumn{2}{|l|}{ Giving offer about marketing actions } \\
\hline \multicolumn{2}{|l|}{ "Dialogue reception" } \\
\hline Checking free appointments & + \\
\hline Informing client about finishing time & + \\
\hline \multicolumn{2}{|l|}{ Client mobility offer } \\
\hline \multicolumn{2}{|l|}{ Informing client about added service advisor and necessary time for reception } \\
\hline \multicolumn{2}{|l|}{ Software preparing for service advisor about agreed business with client } \\
\hline \multicolumn{2}{|l|}{ VEHICLE RECEPTION } \\
\hline Refinement reasons of coming and change statement on the work order if necessary & + \\
\hline Do test drive if necessary and fulfill check list & + \\
\hline \multicolumn{2}{|l|}{ Accessories offer } \\
\hline Visual check of the vehicle with client (option "dialogue reception") and fulfilling the check list & + \\
\hline Explanation about required work and write down the agreed price and finishing time & + \\
\hline \multicolumn{2}{|l|}{ Printing 2 work orders (one for client and one for the workshop) } \\
\hline \multicolumn{2}{|l|}{ Provide transport for client if it is necessary } \\
\hline \multicolumn{2}{|l|}{ VEHICLE REPAIRING } \\
\hline Taking over a work order form reception by workshop & + \\
\hline Repair work by technicians following brand standard including technical report & + \\
\hline $\begin{array}{l}\text { Fulfilling the work report about repair done and completing the whole repair documentation } \\
\text { (paper and/or electronic form) }\end{array}$ & + \\
\hline Informing the reception about additional work & + \\
\hline \multicolumn{2}{|l|}{ Informing client about additional work and fulfilling calling time on the work order } \\
\hline Washing and parking at properly parking place & + \\
\hline Giving the work order to chief of the workshop & + \\
\hline Doing final test drive if necessary & + \\
\hline Giving the work order to the service advisor & + \\
\hline \multicolumn{2}{|l|}{ VEHICLE DELIVERY } \\
\hline Preparing and norming of work time & + \\
\hline \multicolumn{2}{|l|}{ Calling client and informing about finished work } \\
\hline \multicolumn{2}{|l|}{ Following the payment } \\
\hline \multicolumn{2}{|l|}{ Making an invoice with all necessary data } \\
\hline Fulfilling of the service book & + \\
\hline Doing final test drive with client & + \\
\hline Accompany client to the vehicle & \\
\hline
\end{tabular}

\section{Car repairing}

This is a step that directly affects the vehicle returning in service and satisfaction of the customer. In this phase of the service process, as can be seen in Table 3, the quality control should have control over all activities. This includes the process of repair, service reports about performed work, information about extension of work, the final test drive, respecting the promised time, car wash, parking at proper place and delivery of service account to the reception sector. 
A "check list" is used in control, as shown in Table 3. With this kind of control which is done by the Quality control, chances of vehicle returning to service and complaining about the repair are reduced to a minimum. That is a way of improving the traffic safety, and also the client confidence in his own car service.

Table 3: "Check list"

\begin{tabular}{|l|l|}
\hline \multicolumn{1}{|c|}{ Activity } & $\begin{array}{c}\text { Checked/done } \\
\text { (YES/NO) }\end{array}$ \\
\hline Exterior and interior lights & \\
\hline $\begin{array}{l}\text { Horn function, glove compartment light } \\
\text { and trunk light }\end{array}$ & \\
\hline Tires & \\
\hline Battery & \\
\hline $\begin{array}{l}\text { Wiper blades and washer system } \\
\text { functionality }\end{array}$ & \\
\hline $\begin{array}{l}\text { Engine coolant system - level and freezing } \\
\text { point }\end{array}$ & \\
\hline Drain water - permeability & \\
\hline Brake fluid & \\
\hline Steering fluid & \\
\hline Body damages & \\
\hline Engine, gearbox and joint protective boot & \\
\hline $\begin{array}{l}\text { Suspension system (stabilizer, rods and } \\
\text { axles) }\end{array}$ & \\
\hline Brake system & \\
\hline Brake discs and pads thickness -functionality & \\
\hline Toothed belt & \\
\hline Engine oil - changing & \\
\hline Air filter element - changing & \\
\hline Fuel filter - changing & \\
\hline Air conditioning - changing & \\
\hline Setting of the service interval & \\
\hline System faults - diagnosis & \\
\hline Test drive & \\
\hline Client informed about additional work & \\
\hline Agreed finishing time & \\
\hline Washing & \\
\hline Properly parked & \\
\hline Service book fulfilled & \\
\hline
\end{tabular}

\section{Car delivery}

The reception sector delivers vehicles when repair has been done, i.e. the service advisor who was leading the case. Calling the client and car delivery, demand preparation by the service advisor. That includes making the price for services (labor time multiplicities with the hourly working price). This step should also be checked by Quality control, in order to avoid unnecessary payment for some job positions or on the other hand, to avoid not paying for some already done work. The service book is completed, performed work being written and stamped by authorized auto service, as well as additional stamps for road assistance and free towing.

\section{CONCLUSION}

A lot of process activities are recognized which are necessary to follow and control. That is the only way to provide the quality of service that consumers expect. Quality control is the process which is provided by independent quality controller and means operational checks and required corrections. If there is no Quality control in a company whose main activity is to maintain vehicles, the possibility of mistakes is increased, which may be very expensive. Further research should be made considering the benefits of implementing Quality control into service garages.

\section{REFERENCES}

1) Groonros C., (1984), A Service Quality model and ots marketing implications, European Journal of Marketing, Vol. 18 Iss: 4, pp. 36-44.

2) Parasuraman C., Zeithaml V.A., Berry L.L., (1988), SERVQUAL: A Multiple-Item Scale for measuring Consumer Perceptions of Service Quality, Journal of Retailing.

3) Tse D., Wilton P., (1988), Models of Consumer Satisfaction: An Extension, Journal of Marketing Research, Vol. 25, No. 2.

4) Uskoković P.,(2005), Planiranje-jedna od osnovnih aktivnosti menadžmenta, Journal of Applied Engineering Science (Istraživanja i projektovanja za privredu), vol.3, No.8, pp. 33-40

5) Veljkovic S., (2009), Marketing usluga, Centar za izdavačku delatnost Ekonomskog fakulteta u Beogradu, Beograd.

6) VujanovićN., (2003), Odgovornostrukovodstva u pogledu planiranja sistema menadžmenta kvalitetom, Journal of Applied Engineering Science (Istraživanja i projektovanja za privredu), vol. 1, No.1, pp. 49-53

7) www.fpps.edu.rs - Legal and business studies

8) www.stat.gov.rs - Statistical office of the Republic of Serbia; Area: Transport and Communications - registered vehicles

9) Zeithaml V. A., Bitner M.J., Gremler D.D., (2006), Service marketing, Mc GrAW Hill, Inter-national edition

Paper sent to revision: 25.04.2013.

Paper ready for publication: 15.05.2013. 